\title{
PERSONALITY DIMENSION AND ITS RELATIONSHIP TO ON-THE-JOB PERFORMANCE
}

\author{
"Enna S. Bodoso \\ **Engr. Albert Joseph Gonzalo M. Monge
}

\begin{abstract}
This study was conducted to determine the relationship between personality dimensions and OJT performance of the BS Information Technology and BS Information Systems graduating students of a state university in the Philippines. Descriptive method of research was used. The participants of this study are the 73 Fourth Year BS Information Technology and 43 BS Information Systems students. A standardized questionnaire on The Five-Factor of Personality Dimensions Model as conceptualized by Costa and McCrae (1992) was used to determine the personality dimensions of the respondents. To determine the OJT Performance of the respondents, a questionnaire on OJT Performance Rating was used. The results of the study shows that the level of the personality dimensions of the respondents in the areas of Neuroticism, Extroversion, Openness to Experience, Agreeableness, Conscientiousness as a whole shows acceptable performance levels and when they are grouped according to course. The level of the OJT performance of the respondents when taken as a whole and when they are grouped according to course are all found to be above average performance levels. There is significant difference between each of the personality dimensions and OJT performance of the respondents when they are grouped according to course and OJT performance of the respondents.
\end{abstract}

Keywords: Personality, OJT Performance, Information Technology, Information Systems.

\section{Introduction}

Higher education institutions in the Philippines play a vital role in the economic, social and cultural advancement of the country. They are recognized as one of the best agents who will bring about development of the nation's human capital through the delivery of quality education and relevant training. Accordingly, they are expected to prepare graduates for employment. Higher education institutions have the economic responsibility to produce graduates with the skills and attitudes that are highly regarded by employers and are considered valuable to the country's prosperity and human capital.

OJT supervisors' feedback can generate evidence on the quality of graduates, their capabilities and performance in the school. Further, it can provide information on proficiencies and qualities they considered very important and useful in the work place. The level of satisfaction as a form of OJT supervisors' evaluation on graduating students is as important as their assessment of the usefulness of the proficiencies needed in the work place. (Anania B. Aquino Ed. D, Casimira O. Del Mundo, Gliceria R. Quizon, 2015).

It is critically important for organizations today to recruit high performing employees. One big question that organizations may find hard to answer is how to separate individuals who will perform well from those who will not. The answer may to some extent relate to the type of personality that one exhibit. For years researchers have investigated how people's personalities affect their performance at work.

Personality can be seen as the motor which drives behavior. It's consistent over time and across situations, and has been proven to predict our success at work over the course of 50 or more years. The most widely accepted model of personality - the 'Big Five' model - uses five distinct scales to describe personality: conscientiousness (the extent to which one is dependable and persistent), emotional stability (one's calmness and self-control), extraversion (a measure of sociability, ambition and narcissism),

*College of Engineering and Information Technology, Carlos Hilado Memorial State College-Alijis Campus, Bacolod City, Negros Occidental, Philippines

** College of Engineering and Information Technology, Carlos Hilado Memorial State College-Alijis

Campus, Bacolod City, Negros Occidental, Philippines 
agreeableness (the extent to which one is cooperative and altruistic), and openness to experience (a measure of creativity and noveltyseeking).

An individual's unique combination of these five factors influences his or her success at work in three main ways. Firstly, it determines how and why we're motivated to achieve certain goals - for example, people who score high on extraversion are more motivated to achieve a goal if there's a reward involved. Secondly, personality affects our mood, which in turn affects the way we respond to people and situations at work. Studies have found that conscientiousness and agreeableness indirectly affect organizational citizenship behavior via their impact of job satisfaction - simply put, if we're happier in our jobs we're more likely to be better 'citizens' at work. Thirdly, our personality profile affects our interpersonal relationships, making it an important determinant of work success when that work involves getting along with other people.

The relationship between personality and job performance has been a frequently studied topic in industrial psychology in the past century (Barrick, Mount \& Judge, 2001). Job performance is a multidimensional construct which indicates how well employees perform their tasks, the initiative they take and the resourcefulness they show in solving problems. Furthermore, it indicates the extent to which they complete tasks, the way they utilize their available resources and the time and energy they spend on their tasks (Boshoff \& Arnolds, 1995; Schepers, 1994). Job performance could be affected by situational factors, such as the characteristics of the job, the organisation and coworkers (Hackman \& Oldham, 1980; Strümpfer, Danana, Gouws \& Viviers, 1998), and by dispositional factors.

Traditionally, industrial psychologists have questioned the usefulness of personality measures in predicting job-related criteria (such as job performance), because of pessimistic conclusions of early reviews of the topic (e.g. Guion \& Gottier, 1965) and concerns that most personality measures are faked (Reilly \& Warech, 1993). However, evidence has suggested that personality measures are valid predictors of diverse job-related criteria (Goldberg, 1993).

In this research, the relationship between personality dimensions and job performance of the OJT students of Carlos Hilado memorial State College- Alijis was studied from a trait perspective, and more specifically the five-factor model of personality dimensions as conceptualized by Costa and McCrae (1992). The five-factor model of personality represents a structure of traits, developed and elaborated over the last five decades. Factors are defined by groups of intercorrelated traits, which are referred to as facets (McCrae \& Costa, 1997). The five factor model of personality as measured by the Neo-Personality Inventory Revised (NEO-PI-R) includes Neuroticism, Extraversion, Openness, Agreeableness and Conscientiousness (McCrae \& Costa, 1997).

\section{Review of Related Literature}

Walmsley, P. T., Sackett, P. R., \& Nichols, S. B. (2018) examined 123 data sets from validation studies of a single five-factor model-based occupational personality measure for evidence of curvilinear relationships with job performance. Research has produced discrepant findings about whether and when to expect curvilinear relationships between normal range personality measures and job performance. Previous studies have relied on small and unsystematic sampling, a variety of noncomparable performance criteria, the use of personality inventories for which construct validity evidence is not immediately available, and a focus on only one or two of the Big Five personality factors. We report minimal evidence of curvilinearity, suggesting that these effects are unlikely to undermine typical uses of personality test scores in decision making. Any expected declines in performance at high ends of the predictor range were very small on average and would be highly unlikely to produce scenarios in which those passing a realistic cut score would underperform those screened out. Indices of job complexity and the importance of the personality trait did not moderate the forms of each personality-performance relationship. The results are useful for evaluating whether curvilinearity is likely to be an issue when self-report personality assessments are used to make decisions with tangible employment consequences.

According to Davies, W., \& McDonald, A. (2018), organisations increasingly seek to understand more about candidates' potential fit to the job role, a key determinant of engagement. In this context, fit is not about having the qualifications, skills or knowledge to do the job, or even the specific behaviours someone typically displays, but whether the person's values, attitudes and needs are aligned with those of the organisation. Most often this is assessed at an organisational level (e.g. "does this person share the values of the wider organisation?"), but they may also be at a more macro level, such as the work unit or specific team. This focus on fit represents a shift from looking primarily at the 'can do' to considering the 'will do'. Schmidt and colleagues' work concludes that person-organisation fit measures have an overall 
low predictive validity, but what exactly constitutes 'fit' and what outcomes it affects are unclear. Whilst fit may be weakly related to performance, it does show stronger relationships with turnover intentions and positive work attitudes9. Fit is most often assessed by looking at the match between an individual's values and those of the organisation, but questions remain about how best to understand values at an organisational level and how to relate these to individual candidate's needs and expectations.

A study done by Hussain, S., \& Soomro, F. Q. (2018) entitled "Role of Employee Training in Enhancing Perceived Performance through competencies in Services Industry- A Study of Pakistani Banking Sector" is quantitative research with post-positivist approach. Data was collected from 152 bankers from different banks in Karachi through a survey questionnaire. Data was analyzed by applying descriptive analysis and statistical tests. Results revealed that there exists substantial relationship between (IV-1) On-Job-Training, (IV2) Training Design and Delivery and (DV) Perceived Performance, although (IV-3) Off-JobTraining proved as weak predictor. The study produced useful information for future researches.

A study was conducted by Sri Indarti, Solimun, Adji Achmad Rinaldo Fernandes, Wardhani Hakim, (2017) to know whether organizational citizenship behavior mediates the effects of personality, organizational commitment, and job satisfaction. This research was conducted in the city of Makassar with the entire population being lecturer with the status from a permanent lecturer foundation. By using the Slovin formula, a sample of 295 respondents was obtained. Structural equation modeling (SEM) was used as an inferential statistical analysis technique to test the hypothesis of the research. The results of the study found the mediating effect (indirect effect) of variable organizational citizenship behavior was found in between personality, organizational commitment and job satisfaction on performance, which thus indicates that the higher the personality, organizational commitment and job satisfaction the higher the performance, and if mediated, organizational citizenship behavior is also higher.

Another study by Mary Agnes Wambui Kiarie, Loice C. Maru, Thomas Kimeli Cheruiyot, (2017) entitled Leader personality traits and employee job satisfaction in the media sector, Kenya was conducted to determine the effect of leader personality traits on employee job satisfaction. A leader personality trait on employee job satisfaction remains a cause of concern in the contemporary business environment. The study employed an explanatory research design to establish the cause- effects between leader personality traits and employee job satisfaction. Path goal theory and Big Five-factor model of personality traits underpinned the study. Questionnaire was used to obtain data pertaining to the model's constructs. A multiple regression equation model tested the hypotheses.The study showed that leader extraversion; openness to new experiences; emotional stability; conscientiousness and agreeableness have significant effects on employee job satisfaction. The study thus concluded that leaders who portray extraversion; openness to new experiences; emotional stability; conscientiousness and agreeableness enhance employee job satisfaction.

\section{Objectives of the Study}

This study aimed to determine the relationship between personality dimensions and OJT performance of the BS Information Technology and BS Information Systems graduating students of Carlos Hilado Memorial State College - Alijis Campus, Bacolod City for AY 2016-2017.

Specifically, this study sought to answer the following inquiries:

1. What is the level of the personality dimensions of the respondents in the areas of Neuroticism, Extroversion, Openness to Experience, Agreeableness, Conscientiousness as a whole and when they are grouped according to course?

2. What is the level of the OJT performance of the respondents when taken as a whole and when they are grouped according to course?

3. Is there a significant relationship between personality dimensions (Neuroticism, Extroversion, Openness to Experience, Agreeableness, Conscientiousness) and OJT performance of the respondents when they are grouped according to course?

4. Is there a significant relationship between personality dimensions (Neuroticism, Extroversion, Openness to Experience, Agreeableness, Conscientiousness,) and OJT performance of the respondents?

\section{Schematic Diagram}

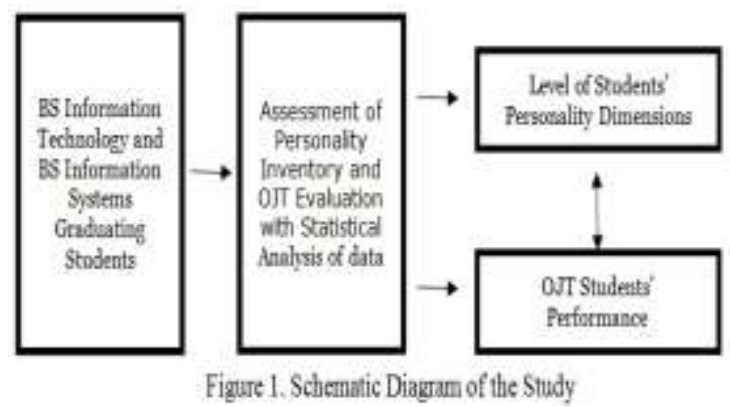




\section{Methods and Materials}

\section{Research Design}

The study used the descriptive survey method of research employing a survey questionnaire to collect data needed. Descriptive research "is designed to provide a picture of a situation as it naturally happens" (Burns and Grove, 2013).

\section{Respondents of the Study}

The participants of this study were the 73 Fourth Year BS Information Technology and 43 BS Information Systems students of CHMSC-Alijis Campus who are having their (On-the-job Training) OJT for the Second Semester Academic Year 2016-2017. The stratified random sampling was used in this study.

\section{Research Instruments}

A standardized questionnaire on The Five-Factor of Personality Dimensions Model as conceptualized by Costa and McCrae (1992) was used to determine the personality dimensions of the respondents. The five-factor model of personality represents a structure of traits. Factors are defined by groups of intercorrelated traits, which are referred to as facets (McCrae \& Costa, 1997). The five factor model of personality as measured by the Neo-Personality Inventory Revised (NEO-PI-R) includes Neuroticism, Extraversion, Openness, Agreeableness and Conscientiousness.

To determine the OJT Performance of the respondents, a questionnaire on OJT Performance Rating was used which is the instrument used by the school's OJT Supervisor in monitoring students' performance.

\section{Results and Discussion}

Level of Personality Dimensions as a Whole and when Respondents are Grouped According to Course

Table 1. Level of Personality Dimensions as a Whole and when Respondents are Grouped According to Course

\begin{tabular}{|c|c|c|c|c|c|}
\hline Course & $\begin{array}{cc}\text { Extraversion } \\
\text { M SD }\end{array}$ & $\begin{array}{c}\text { Agreeableness } \\
\text { M SD }\end{array}$ & $\begin{array}{c}\text { Conscientiousness } \\
\text { M SD }\end{array}$ & $\begin{array}{cc}\text { Neuroticism } \\
\text { M SD }\end{array}$ & $\begin{array}{c}\text { Openness } \\
\text { Experience } \\
\mathrm{M} \quad \mathrm{SD}\end{array}$ \\
\hline $\begin{array}{l}\text { BS Info } \\
\text { Tech }\end{array}$ & $3.02 \quad .370$ & $3.23 \quad .312$ & $3.25 \quad .350$ & 2.79 .569 & $3.13 \quad .344$ \\
\hline $\begin{array}{l}\text { BS Info } \\
\text { System }\end{array}$ & $3.08 \quad .390$ & $3.34 \quad .366$ & $3.25 \quad .326$ & $2.94 \quad .470$ & $3.11 \quad .320$ \\
\hline $\begin{array}{ll}\text { As } & \text { a } \\
\text { whole } & \end{array}$ & 2.8 & 3.05 & 3.0 & 2.65 & 2.9 \\
\hline
\end{tabular}

Note.BS Info System $n=43$. BS Info Tech $\mathrm{n}=73$. Higher scores indicate a greater magnitude of each variable.

Level of OJT Performance as a Whole and when Respondents are Grouped According to Course
Table 2. Level of OJT Performance as a Whole and when Respondents are Grouped According to Course

\begin{tabular}{|l|l|l|l|l|l|l|l|l|l|}
\hline General Workplace Performance \\
\hline Course & $\begin{array}{l}\text { Atte } \\
\text { nda } \\
\text { nce }\end{array}$ & $\begin{array}{l}\text { Pun } \\
\text { ctua } \\
\text { lity }\end{array}$ & $\begin{array}{l}\text { Appr } \\
\text { opria } \\
\text { te } \\
\text { dress }\end{array}$ & $\begin{array}{l}\text { Attit } \\
\text { ude }\end{array}$ & $\begin{array}{l}\text { Acce } \\
\text { ptanc } \\
\text { e of } \\
\text { critici } \\
\text { sm }\end{array}$ & $\begin{array}{l}\text { Asks } \\
\text { appr } \\
\text { opria } \\
\text { te } \\
\text { quest } \\
\text { ions }\end{array}$ & $\begin{array}{l}\text { Self- } \\
\text { motiv } \\
\text { ated }\end{array}$ & $\begin{array}{l}\text { Pract } \\
\text { ices } \\
\text { ethic } \\
\text { al } \\
\text { beha } \\
\text { viour }\end{array}$ & $\begin{array}{l}\text { Overall } \\
\text { Mean }\end{array}$ \\
\hline BS Info System & 3.70 & 3.70 & 3.86 & 4.02 & 3.81 & 3.81 & 3.93 & 3.98 & $\mathbf{3 . 8 5}$ \\
\hline BS Info Tech & 4.22 & 4.11 & 4.30 & 4.47 & 4.40 & 4.33 & 4.49 & 4.44 & $\mathbf{4 . 3 4}$ \\
\hline As a whole & 3.96 & 3.91 & 4.08 & 4.24 & 4.11 & 4.07 & 4.21 & 4.21 & $\mathbf{4 . 1 0}$ \\
\hline Verbal Interpretation & AAP & AAP & AAP & SP & AAP & AAP & SP & SP & AAP \\
\hline
\end{tabular}




\begin{tabular}{|c|c|c|c|c|c|c|c|c|c|}
\hline \multicolumn{10}{|c|}{ Specific Job Assignment Performance } \\
\hline & $\begin{array}{l}\text { Suffi } \\
\text { cient } \\
\text { kno } \\
\text { wled } \\
\text { ge to } \\
\text { perfo } \\
\text { rm } \\
\text { tasks }\end{array}$ & $\begin{array}{l}\text { Verb } \\
\text { al } \\
\text { com } \\
\text { muni } \\
\text { catio } \\
\text { n } \\
\text { skills }\end{array}$ & $\begin{array}{l}\text { Writt } \\
\text { en } \\
\text { comm } \\
\text { unicat } \\
\text { ion } \\
\text { skills }\end{array}$ & $\begin{array}{l}\text { Analytical } \\
\text { Skills- } \\
\text { analyzes } \\
\text { problems } \\
\text { and takes } \\
\text { appropriat } \\
\text { e action }\end{array}$ & $\begin{array}{l}\text { Uses } \\
\text { technica } \\
1 \text { skills } \\
\text { required } \\
\text { for the } \\
\text { position }\end{array}$ & $\begin{array}{l}\text { Meet } \\
\text { s } \\
\text { dead } \\
\text { lines }\end{array}$ & $\begin{array}{l}\text { Takes } \\
\text { initiative to } \\
\text { get a job } \\
\text { done, } \\
\text { including } \\
\text { overcoming } \\
\text { obstacles }\end{array}$ & $\begin{array}{l}\text { Sets } \\
\text { prior } \\
\text { ities }\end{array}$ & $\begin{array}{l}\text { Overall } \\
\text { Mean }\end{array}$ \\
\hline BS Info System & 3.91 & 3.74 & 3.63 & 3.63 & 3.72 & 3.58 & 3.72 & 3.77 & 3.71 \\
\hline BS Info Tech & 4.29 & 4.05 & 4.01 & 4.29 & 4.29 & 4.25 & 4.32 & 4.29 & 4.22 \\
\hline As a whole & 4.1 & 3.90 & 3.82 & 3.96 & 4.00 & 3.92 & 4.02 & 4.03 & 3.97 \\
\hline Verbal Interpretation & AAP & AAP & AAP & AAP & AAP & AAP & AAP & AAP & AAP \\
\hline
\end{tabular}

\section{Legend}

4.20-5:00 - Superior performance (SP)

3.40-4.19 - Above average performance (AAP)

2.60-3.39 - Acceptable performance (AP)

1.80-2.59 - Performing below expectations (PBE)

1.00-1.79 - Needs more training or education (NMT)

Difference Between Personality Dimensions and OJT Performance

Table 3. Difference in the Personality Dimension- Extraversion when students are grouped according to Course

\begin{tabular}{lcccl}
\hline Variable & Mean & T & df & $\mathrm{p}$ \\
\hline BS Info & 3.02 & 69.76 & 72 & .000 \\
Tech & & & 42 & \\
BSIS & 3.07 & 51.76 & & .000 \\
\hline
\end{tabular}

The table shows the difference in the Personality Dimension-Extraversion when students are grouped according to course.

The results shows that there is a significant difference in the personality dimension in the area of extraversion when respondents are grouped according to course.

Table 4.Difference in the Personality Dimension- Agreeableness when students are grouped according to Course

\begin{tabular}{lcccc}
\hline Variable & Mean & T & df & $\mathrm{p}$ \\
\hline BS Info & 3.23 & & 72 & .000 \\
Tech & & 88.60 & 72 & \\
BSIS & 3.33 & 59.85 & & .000 \\
\hline
\end{tabular}

The table shows the difference in the Personality Dimension-agreeableness when students are grouped according to course.

There is a significant difference in the personality dimension in the area of agreeableness when respondents are grouped according to course.

Table 5. Difference in the Personality Dimension- Conscientiousness when students are grouped according to Course

\begin{tabular}{|c|c|c|c|c|}
\hline Variable & Mean & $\mathrm{T}$ & df & $\mathrm{p}$ \\
\hline $\begin{array}{ll}\text { BS } & \text { Info } \\
\text { Tech } & \end{array}$ & 3.25 & 79.37 & 72 & .000 \\
\hline BSIS & 3.25 & 65.37 & 42 & .000 \\
\hline
\end{tabular}

The table shows the difference in the Personality Dimension-Conscientiousness when students are grouped according to course.

There is a significant difference in the personality dimension in the area of conscientiousness when respondents are grouped according to course.

Table 6. Difference in the Personality Dimension- Neuroticism when students are grouped according to Course

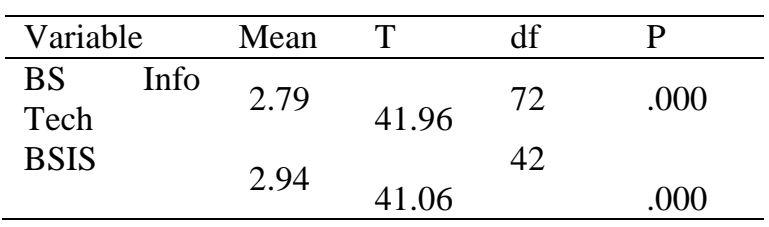

The table shows the difference in the Personality Dimension-Neuroticismwhen students are grouped according to course. 
There is a significant difference in the personality dimension in the area of neuroticism when respondents are grouped according to course.

Table 7. Difference in the Personality Dimension- Openness to Experience when students are grouped according to Course

\begin{tabular}{|c|c|c|c|c|}
\hline Variable & Mean & $\mathrm{T}$ & df & $\mathrm{P}$ \\
\hline $\begin{array}{ll}\text { BS } & \text { Info } \\
\text { Tech } & \end{array}$ & 3.13 & 77.73 & 72 & .000 \\
\hline BSIS & 3.11 & 63.74 & 42 & .000 \\
\hline
\end{tabular}

The table shows the difference in the Personality Dimension-Openness to Experience when students are grouped according to course.

There is a significant difference in the personality dimension in the area of openness to experience when respondents are grouped according to course.

\section{Table 8. Difference in the Level of OJT Performance when students are grouped according to Course}

\begin{tabular}{|c|c|c|c|c|}
\hline Variable & Mean & $\mathrm{T}$ & $\mathrm{df}$ & $\mathrm{P}$ \\
\hline $\begin{array}{ll}\text { BS } & \text { Info } \\
\text { Tech } & \end{array}$ & 4.28 & 56.99 & 72 & .000 \\
\hline BSIS & 4.03 & 48.60 & 42 & .000 \\
\hline
\end{tabular}

The table shows the difference in the level of OJT Performance when students are grouped according to course.

There is a significant difference in the level of OJT Performance when respondents are grouped according to course.

\section{Relationship Between Personality Dimensions and OJT Performance}

\section{Table 9. Relationship Between Personality Dimensions and OJT Performance}

\begin{tabular}{|c|c|c|c|}
\hline & & iversion & Agreeableness \\
\hline \multirow{2}{*}{$\begin{array}{l}\text { OJT } \\
\text { Performance }\end{array}$} & $\mathrm{p}$ & 103 & .007 \\
\hline & $\mathrm{r}$ & .272 & .944 \\
\hline
\end{tabular}

There is a significant relationship between Agreeableness and OJT Performance.

There is a significant relationship between Conscientiousness and OJT Performance.
There is a significant relationship between Openness to Experience and OJT Performance.

\section{Summary of Findings}

1. The level of the personality dimensions of respondents as a whole shows high mean on Agreeableness (3.05) and Conscientiousness (3.0). The respondents when they are grouped according to course, BS Information Technology shows high mean on Agreeableness (3.23) and Conscientiousness (3.25); BS Information Systems shows high mean on Agreeableness (3.34) and Conscientiousness (3.25).

2. The BS Information Technology students show superior performance on Specific Job Assignment which is (4.22)mean score and General Workplace Performance which is (4.35) mean score.

3. The level of the OJT performance of the respondents when taken as a whole and when they are grouped according to course are all found to be above average performance levels.

4. There is a significant difference between each of the personality dimensions (Neuroticism, Extroversion, and Openness to Experience, Agreeableness, and Conscientiousness) and OJT performance of the respondents when they are grouped according to course.

5. There is a significant difference between each of the personality dimensions (Neuroticism, Extroversion, Openness to Experience, Agreeableness, Conscientiousness,) and OJT performance of the respondents.

\section{Conclusions}

The results of the study confirms that there is association between the personality dimensions and OJT Performance of students in both BS Information Technology and BS Information Systems. The personality dimensions of Conscientiousness and Agreeableness are the strongest traits for the OJT Students of the College when grouped into course and as a whole. This means they perform at an above average performance on Analysis of problems, initiative and technical skills. Surprisingly, results show

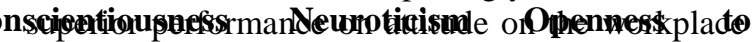
performance. The dimensions of agFexpriense and

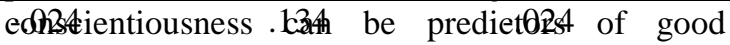
performance in the workplace and this can give reditifters insight .\$\$3 the kind o799ood future employees they wanted to have. Further, personality inventory in the industry is still a good aiding tool in employees' decisions. 


\section{Recommendations}

1. The findings in the present study open possibilities for future research to build on and develop. The findings yield the dimensions of Agreeableness and Conscientiousness as the common personality trait for both BS Information Technology and BS Information Systems, thus, it is recommended that further investigation on the sub dimensions of the Big Five factors be made.

2. Further, personality dimension assessment and Job performance rating may be investigated for other programs of the college having similar off campus Internship or On the Job Training

3. It is recommended that the ratings of $\mathrm{BS}$ Information Technology and Information Systems OJT Students be used for curriculum review and enhancement.

4. Further, it is recommend that triangulation of evaluation from OJT Students, Employers, and Teachers to get more insights of performance on the job.

\section{References}

1. Anania B. Aquino (Ed.D), Casimira O. Del Mundo, Gliceria R. Quizon (2015). Employers' Feedbacks on the Performance of Teacher Education Graduates. Asia Pacific Journal of Multidisciplinary Research, Vol. 3, No. 4, November 2015 Part II.

2. Can Personality Predict Performance? Retrieved September 29, 2016. Available online

http://www.forbes.com/sites/sebastianbailey/2 014/07/08/can-personality-predictperformance/\#6ef509821fa0

3. Davies, W., \& McDonald, A. (2018). Predicting Job Performance at Recruitment.

4. Goldberg, Lewis R. "The development of markers for the Big-Five factor structure." Psychological assessment 4.1 (1992): 26. <http://dx.doi.org/10.1037/1040-3590.4.1.26> Retrieved November 14, 2016 from http://personality-testing.info/tests/IPIPBFFM/
5. Hussain, S., \& Soomro, F. Q. (2018). Role of Employee Training in Enhancing Perceived Performance through competencies in Services Industry-A Study of Pakistani Banking Sector. Pakistan Business Review, 20(1), 122-136. Retrieved from https://journals.iobmresearch.com/index.php/P $\mathrm{BR} /$ article/view/2284.

6. Kiarie, ,Mary Agnes Wambui , Maru , Loice C. , and Cheruiyot, Thomas Kimeli , (2017) "Leader personality traits and employee job satisfaction in the media sector, Kenya", The TQM Journal, Vol. 29 Issue: 1, pp.133-146, https://doi.org/10.1108/TQM-09-2015-0117

7. Sri Indarti, Solimun, Adji Achmad Rinaldo Fernandes, Wardhani Hakim, (2017) "The effect of OCB in relationship between personality, organizational commitment and job satisfaction on performance", Journal of Management Development, Vol. 36 Issue: 10, pp.1283-1293, https://doi.org/10.1108/JMD11-2016-0250

8. The Big Five Personality Test. Available online at http://personalitytesting.info/printable/big-five-personalitytest.pdf

9. The Relationship Between Personality And Job Performance In Sales. Available online at

10. http://Www.DynamicWork.Se/Images/Uploads/Bilder/The-

Relationship-Between-Personality-Och-JobPerformance-In-Sales_Dynamic-WorkSolutions.Pdf

11. The Big Five Personality Dimensions and Job Performance. Available online at

12. http://Www.Ianrothmann.Com/Pub/Psyc_V29 _N1_A9.Pdf

13. Personality And Job Performance - A Review. Available online at

14. http://Www.ScontrinoPowell.Com/2014/Personality-And-JobPerformance-A-Review/

15. Walmsley, P. T., Sackett, P. R., \& Nichols, S. B. (2018). A large sample investigation of the presence of nonlinear personality-job performance relationships. International Journal of Selection and Assessment, 26(2-4), 145-163. https://doi.org/10.1111/ijsa.12223 